MINERALOGIA POLONICA

10.2478/v10002-007-0005-x

PL ISSN 0032-6267

Vol. 37, No 1, 2006

Jaroslav PRŠEK ${ }^{1}$, Emil MAKOVICKY ${ }^{2}$, Martin CHOVAN ${ }^{1}$, Alexander SMIRNOV ${ }^{3}$

\title{
A NOTE ON THE CHEMICAL COMPOSITION OF NUFFIELDITE SOLID-SOLUTION FROM SULPHIDE MINERALIZATIONS IN THE WESTERN CARPATHIANS, SLOVAKIA
}

\author{
Received 7 January 2006; accepted 14 June 2006
}

A b s tr a ct. The chemistry of the rare sulphosalt nuffieldite from three localities in Slovakia is examined. Nuffieldite is a part of a complex association of Bi sulphosalts accompanying tetrahedrite mineralization in some sulphide deposits in the Western Carpathians. $\mathrm{Cu}+\mathrm{Pb}=(\mathrm{Bi}, \mathrm{Sb})+$ vac. substitution in nuffieldite and the general formula $\mathrm{Cu}_{1+\mathrm{x}} \mathrm{Pb}_{2} \mathrm{Bi}_{2}\left(\mathrm{~Pb}_{\mathrm{x}} \mathrm{Sb}_{\mathrm{y}} \mathrm{Bi}_{1-\mathrm{x}-\mathrm{y}}\right) \mathrm{S}_{7}$ where $0<\mathrm{x}<0.34$; and $0.32<\mathrm{y}<0.45$ are confirmed. Decreasing $\mathrm{Sb}$ content with increasing copper content indicates a predominant substitution of $\mathrm{Bi}$ by $\mathrm{Sb}$ in nuffieldite.

Key-words: nuffieldite, Bi sulphosalts, chemical composition, $\mathrm{Cu}+\mathrm{Pb}=(\mathrm{Bi}, \mathrm{Sb})+\square$ substitution

\section{INTRODUCTION}

Nuffieldite, a complex Pb-Bi-Cu sulphosalt, was discovered by Kingston (1968) in the Lime Creek molybdenum deposit, British Columbia. He proposed a formula $\mathrm{Pb}_{10} \mathrm{Bi}_{10} \mathrm{Cu}_{4} \mathrm{~S}_{27}$ and an orthorhombic symmetry with $\mathrm{a}=14.61, \mathrm{~b}=21.38$ and $\mathrm{c}=4.03 \AA$. Its structure was first solved by Kohatsu and Wuensch (1973) using Kingston's chemical data, and the formula was refined as $\mathrm{Pb}_{2} \mathrm{Cu}(\mathrm{Bi}, \mathrm{Pb}) \mathrm{Bi}_{2} \mathrm{~S}_{7}$. A second occurrence was described from the Spišsko-Gemerské Rudohorie Mountains (Slovakia) by Hurný and Krištín (1978). According to Moëlo (1989), the presence of antimony in the structure (Les Houches, France) could stabilize nuffieldite in nature. Maurel and Moëlo (1990) synthesized nuffieldite with as much as $4.1 \mathrm{wt} \% \mathrm{Sb}$ at $435^{\circ} \mathrm{C}$. Taking into account

\footnotetext{
1 Department of Mineralogy and Petrology, Comenius University, Mlynská dolina 842 15, Bratislava, Slovakia.

2 Department of Mineralogy, Geological Institute, University of Copenhagen, Øster Voldgade 10, DK1350 Copenhagen K, Denmark.

3 Department of Geosciences, State University of New York, Stony Brook, NY 11794-2100, USA.
} 
the structural role of antimony, Moëlo (1989) proposed $\mathrm{Pb}_{2} \mathrm{Cu}_{1+\mathrm{x}}\left(\mathrm{Pb}_{\mathrm{x}} \mathrm{Bi}_{1-\mathrm{x}-\mathrm{y}} \mathrm{Sb}_{\mathrm{y}}\right) \mathrm{Bi}_{2} \mathrm{~S}_{7}$ as a formula for nuffieldite with a possibility of the "aikinite-type" substitution $\left(\mathrm{Bi}^{3+}+\right.$ vac. $\left.=\mathrm{Pb}^{2+}+\mathrm{Cu}^{+}\right)$. Antimony in the nuffieldite structure was reported also from other occurrences: Lime Creek and Izok Lake in Canada (Harris 1993) and the Maleevskoe deposit in Russia (Yudovskaya et al. 1992; Mozgova et al. 1994) from which nuffieldite with 1.6-4.2 $\mathrm{wt} \% \mathrm{Sb}$ was described. Oversubstituted, Sb-free nuffieldite with copper $(x=0.65)$ was reported by Ciobanu and Cook (2000) from Ocna de Fier (Romania). The position of excess copper in the structure was determined by Moëlo et al. (1997) in material from the Les Houches deposit. Moëlo et al. (1997) demonstrated a clear similarity of the rod element interfaces in aikinite and nuffieldite. It is these interfaces that host both the "regular" and the "excess" copper sites in nuffieldite.

Nuffieldite described in this paper was discovered at three different localities of siderite mineralization in Slovakia: the Mlynná dolina valley - close to Hviezda (next in the text only Hviezda) the Bruchatý grúnik occurrences in the Nízke Tatry Mts and the Slovinky deposit in the Spišsko-Gemerské Rudohorie Mts. Nuffieldite occurs at all localities in association with other bismuth sulphosalts, galena, chalcopyrite and tetrahedrite as a part of complex quartz-siderite-sulphide assemblages.

\section{GEOLOGICAL SETTING AND ORE MINERALIZATION}

The quartz-siderite-sulphide veins with bismuth sulphosalts occur in the western part of the Nízke Tatry Mts in the Tatric Tectonic Unit and in the Spišsko-Gemerské Rudohorie Mts in the Gemeric Tectonic Unit (Fig. 1). The Bruchatý grúnik mineralization is located in granodiorite and at the contact of gneiss with granitoid. It is

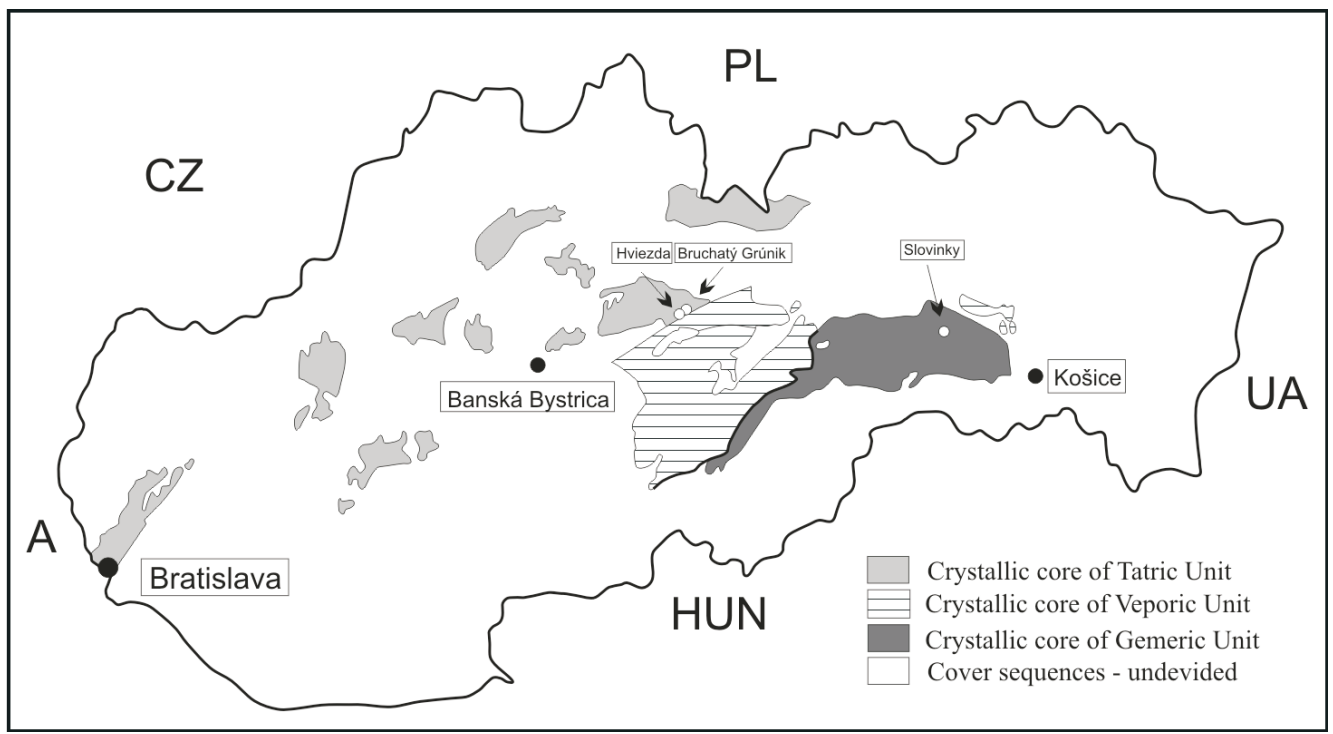

Fig. 1. Simple geological sketch map of Slovakia with the nuffieldite localities marked 
characterized by the presence of abundant medium-grained ankerite and sulphides and sulphosalts: galena, Ni-Co minerals and tetrahedrite (Ozdín, Chovan 1999). The quartz veins in the Hviezda area carry abundant chalcopyrite and tetrahedrite (Majzlan, Chovan 1997); proudite, kobellite and krupkaite were also occur (Majzlan, Ozdín 1995). The Slovinky deposit is hosted in the low-grade metamorphosed rocks of the Gemeric Tectonic Unit. In this deposit, siderite veins with sulphide mineralization occur in phyllites and metarhyolites and are characterized by abundant chalcopyrite and tetrahedrite and by many other sulphide minerals such as stannite, arsenopyrite, sphalerite, tennantite and Bi sulphosalts (Antal 1991a). Members of the bismuthinite-aikinite series (aikinite, gladite, hammarite, krupkaite) were described together with galenobismutite, cosalite and native bismuth as the minerals of the youngest paragenesis together with tetrahedrite (Antal 1991b).

\section{ANALYTICAL METHODS}

The chemical composition of nuffieldite was determined using a JEOL Superprobe 733 electron microprobe analyser (Geologisk Institut København Universitet, Denmark). The operating conditions were as follows: accelerating voltage $20 \mathrm{kV}$, probe current $20 \mathrm{nA}$ and a beam diameter of $5 \mu \mathrm{m}$. The following standards and spectral lines were used: pure $\mathrm{Ag}(\mathrm{AgL} \alpha)$ and $\mathrm{Sb}(\mathrm{SbL} \alpha)$, synthetic $\mathrm{PbS}(\mathrm{PbL} \alpha)$ and $\mathrm{Bi}_{2} \mathrm{~S}_{3}(\mathrm{BiL} \alpha)$ and natural $\mathrm{CuFeS}_{2}(\mathrm{CuK} \alpha, \mathrm{FeK} \alpha, \mathrm{SK} \alpha)$. The results were corrected using on-line ZAF correction.

\section{MINERAL CHEMISTRY}

In polarized reflected light, most $\mathrm{Cu}-\mathrm{Pb}$-Bi sulphosalts show similar optical properties such as a grey-white to yellowish color and a weak to moderate bireflectance and anisotropism. They are usually closely intergrown and difficult to distinguish from each other. Therefore, back-scattered electron (BSE) imaging was used to discriminate between various phases and to ensure the selection of homogeneous areas for microprobe analyses (Fig. 2A, B). In addition to nuffieldite, several other bismuth sulphosalts were discovered but their description and chemical composition will not be addressed in this paper.

The nuffieldite microprobe analyses from the Slovak occurrences (Table 1) show a wide range of the "aikinite-like" substitution, i.e. $\mathrm{Pb}+\mathrm{Cu}=(\mathrm{Bi}, \mathrm{Sb})+$ vacancy. The Fe content in the samples was $0.00-1.80 \mathrm{wt} \%$ and no other elements were detected in significant concentrations (actual amounts are $<0.10 \mathrm{wt} \%$ ). In the $\mathrm{Cu}-\mathrm{Pb}-\mathrm{Bi}(\mathrm{Sb})$ diagram (Fig. 3), all analyses cluster around the $\mathrm{Cu}+\mathrm{Pb}=(\mathrm{Bi}, \mathrm{Sb})+\square$ substitution line.

In the context of Moëlo's (1989) formula of $\mathrm{Cu}_{1+x} \mathrm{~Pb}_{2} \mathrm{Bi}_{2}\left(\mathrm{Bi}_{1-(x+y)} \mathrm{Pb}_{x} \mathrm{Sb}_{y}\right) \mathrm{S}_{7}$, the $x$ value of the substitution in the nuffieldite samples from the Hviezda occurrence is about 0.06 and reflects nearly unsubstitued nuffieldite. This also agrees with the formula proposed by Kohatsu and Wuensch (1973). This unsubstituted nuffieldite is also characterised by the maximum measured content of antimony in the structure. 

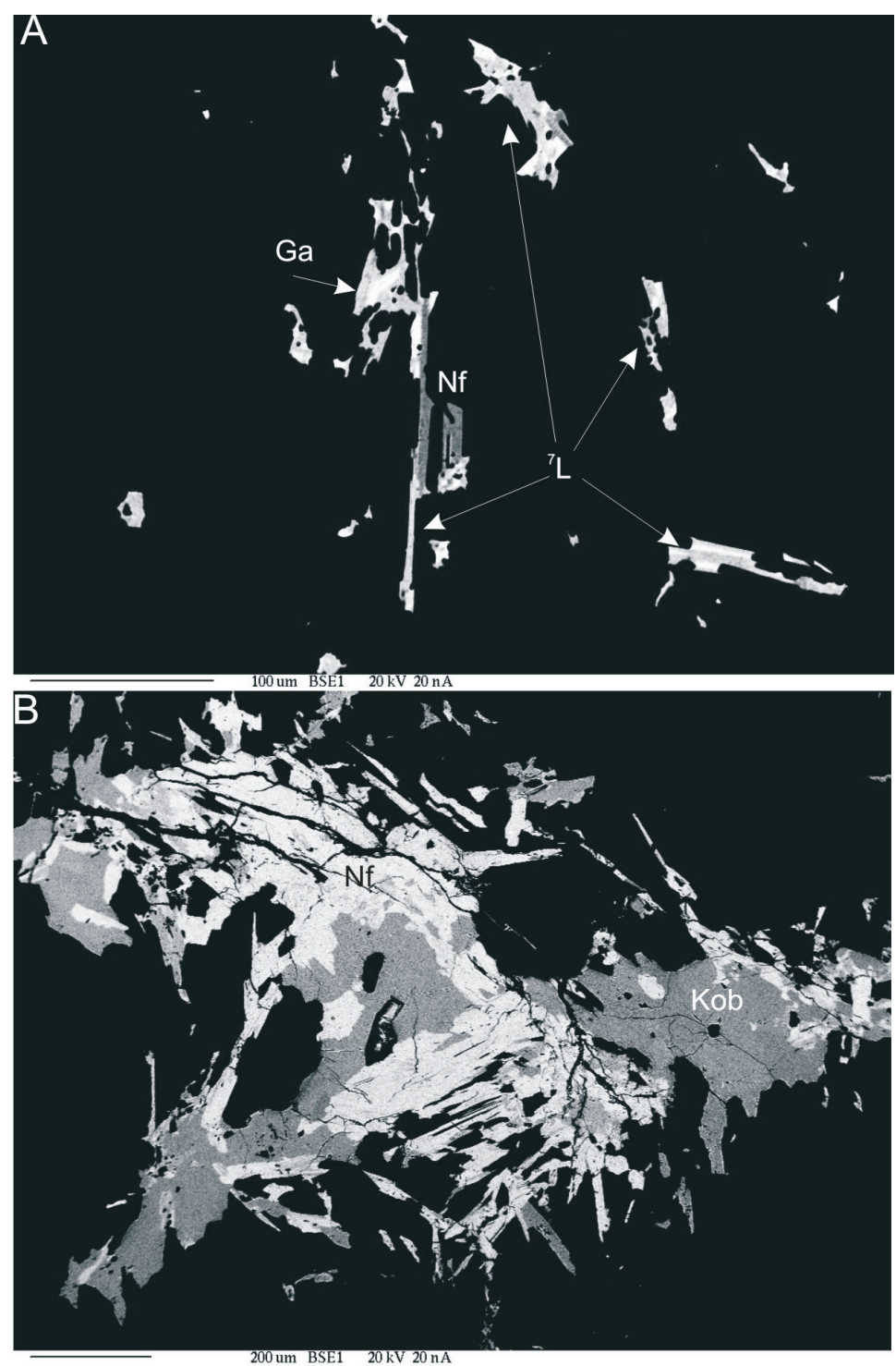

Fig. 2A. Needles of nuffieldite (dark grey) associated with heyrovskýite (light grey) and galena (white) in quartz (black). SEM-BSE image (Bruchatý grúnik) $\mathrm{Nf}$ - nuffieldite, ${ }^{7} \mathrm{~L}-$ heyrovskýite, Ga - galena

2B. Needles of nuffieldite (white) intergrown with kobellite (grey) in quartz (black). SEM-BSE image (Hviezda). Nf - nuffieldite, Kob - kobellite

Its mean composition can be written as $\mathrm{Cu}_{1.06} \mathrm{~Pb}_{2} \mathrm{Bi}_{2}\left(\mathrm{~Pb}_{0.02} \mathrm{Fe}_{0.01} \mathrm{Sb}_{0.45} \mathrm{Bi}_{0.52}\right)_{1} \mathrm{~S}_{7.09}$ calculated on the basis of the $\mathrm{Pb}+\mathrm{Ag}+\mathrm{Bi}+\mathrm{Sb}+\mathrm{Fe}$ total equal to 5 . The values of the $\mathrm{x}$ coefficient for excess $\mathrm{Cu}$ equal to 0.06 , and those of $(\mathrm{Fe}+\mathrm{Pb})$ equal to 0.03 , are nearly identical. Modelled as a mixed almost $\mathrm{Pb}$-free metal position, this site tends towards a Bi:Sb ratio of about 1:1. Nuffieldite from the other two localities studied show a higher 
岢

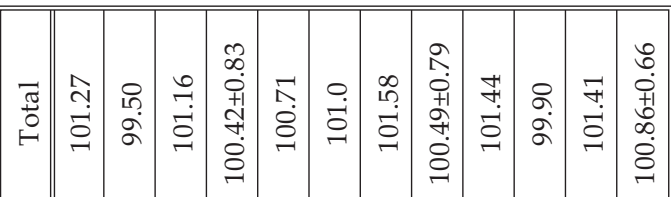

$$
\text { ज }
$$

光

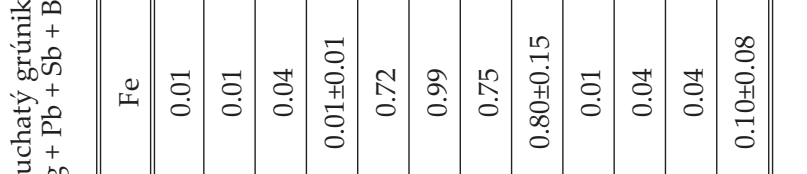

究早

窇.

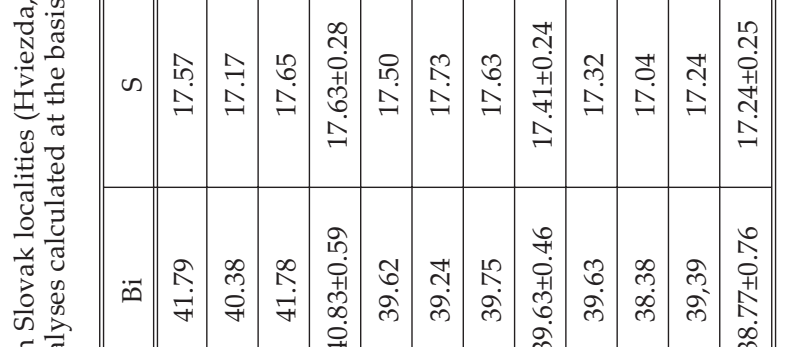

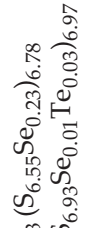

\section{जी}

की

अ के

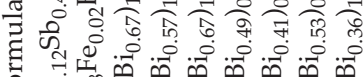

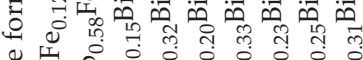

मी की की की की की की

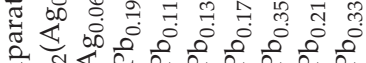

ही मी

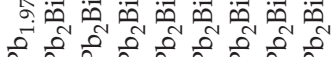

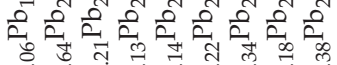

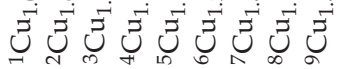

बूँ

离 $\frac{\pi}{\pi}$

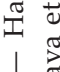

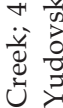

:

कू

1 2

空

芒

हี

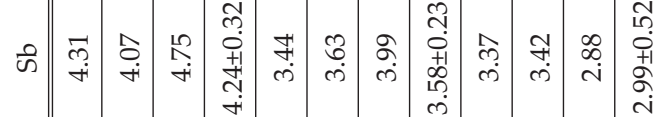

O

$\exists$ है

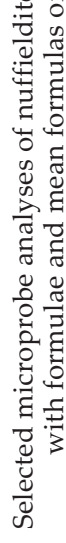

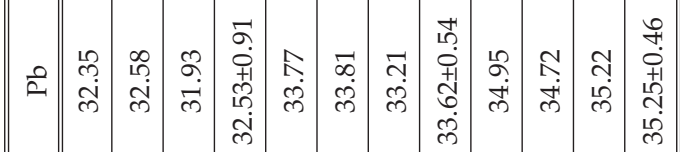

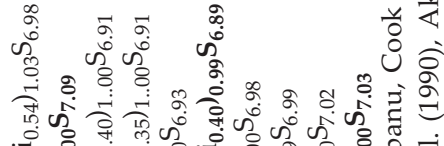

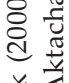
मी की दो ती के की

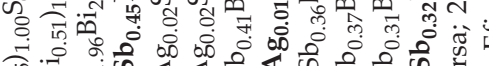
फी

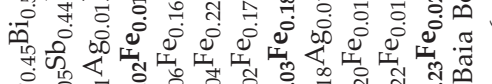

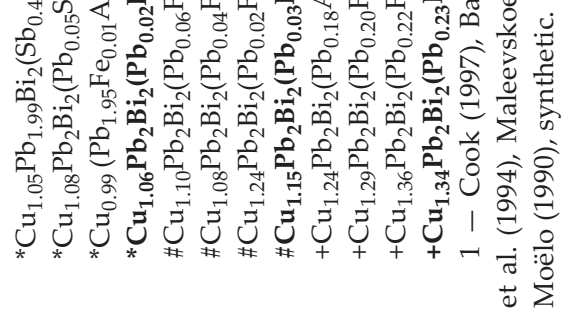




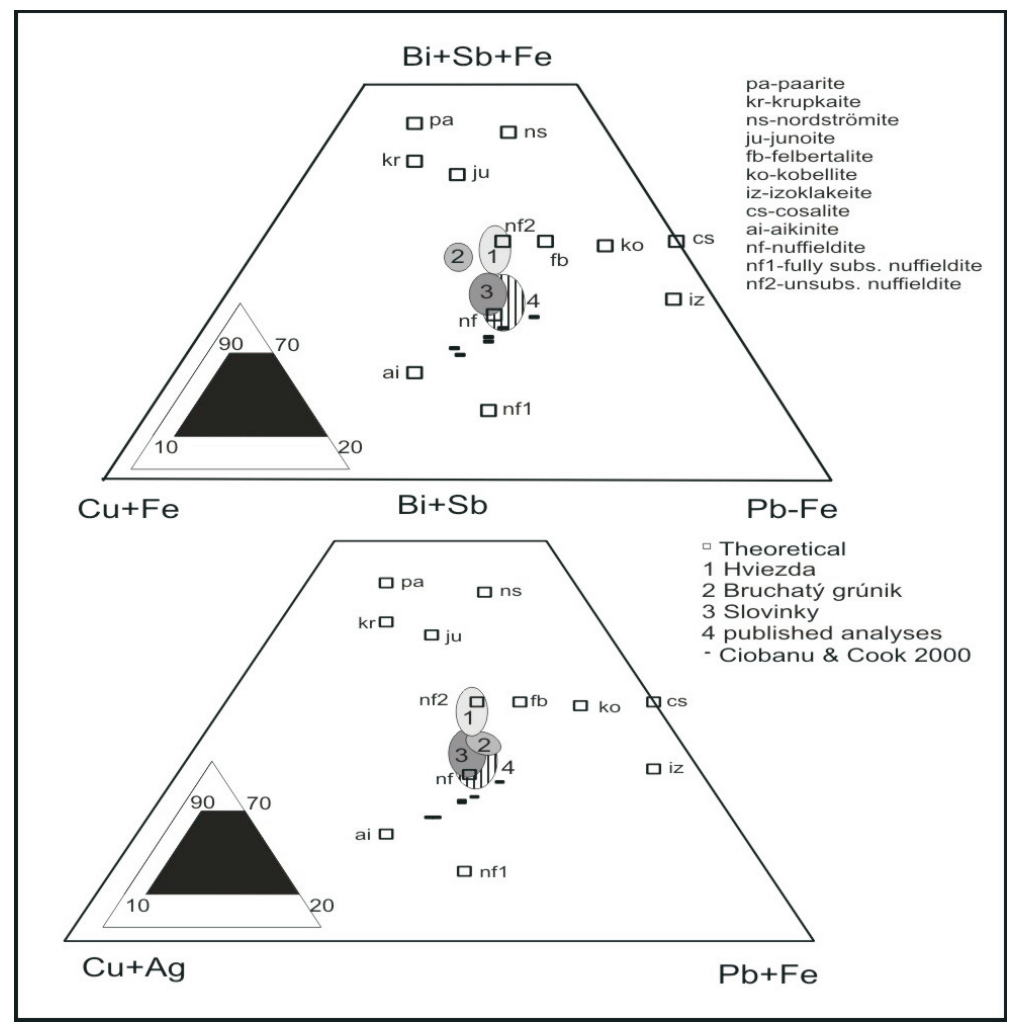

Fig. 3. The role of $\mathrm{Fe}$ in the system $\mathrm{Cu}-\mathrm{Pb}-\mathrm{Fe}-\mathrm{Sb}-\mathrm{Bi}$

degree of substitution of $(\mathrm{Sb}, \mathrm{Bi})$ by $\mathrm{Pb}$; their $\mathrm{x}$ values reach 0.15 and 0.34 for Bruchatý grúnik and Slovinky, respectively. Interestingly, the relative content of antimony slightly decreases with the increasing degree of substitution (Fig. 4). Although this trend is not very distinct, $\mathrm{Sb}$ might be preferentially substituted; the content of an-

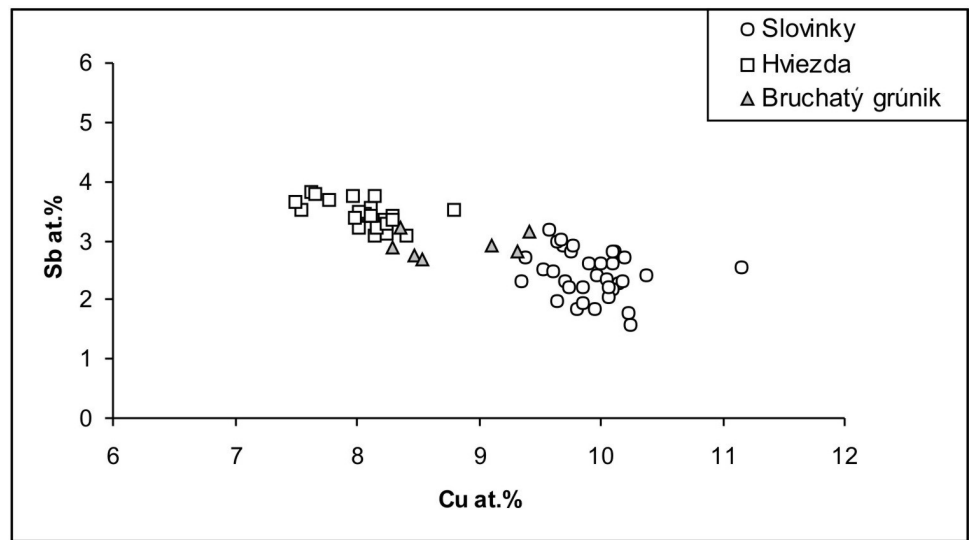

Fig. 4. The correlation of $\mathrm{Sb}$ and $\mathrm{Cu}$ (in wt\%) in nuffieldite 
timony is not controlled by the availability of bismuth only, but partly also by the $\mathrm{Pb}+\mathrm{Cu}$ substitution. The formula for the member with a mean $\mathrm{x}$ coefficient of 0.15 can be written as $\mathrm{Cu}_{1.15} \mathrm{~Pb}_{2} \mathrm{Bi}_{2}\left(\mathrm{Ag}_{0.01} \mathrm{~Pb}_{0.03} \mathrm{Fe}_{0.18} \mathrm{Sb}_{0.37} \mathrm{Bi}_{0.40}\right)_{0.99} \mathrm{~S}_{6.89}$, calculated on the same principle as mentioned above. Again, contents of $x(\mathrm{Cu}$ and $\mathrm{Pb}+\mathrm{Fe})$ are very similar. Calculating Fe together with $\mathrm{Pb}$ yields a higher value for $\mathrm{x}(\mathrm{Pb}+\mathrm{Fe})$ than for $\mathrm{x}(\mathrm{Cu})$, which indicates that some iron present in the analyses is the result of an impurity; the very thin nuffieldite needles are enclosed in siderite.

The unusual Fe-bearing nuffieldite from Bruchatý grúnik (Table 1) prompted a closer investigation of its position in the compositional triangle (Fig. 3) and of its possible affinity to the kobellite homologous series. Using the formulae derived for the kobellite homologous series by Zakrzewski and Makovicky (1986), with $\mathrm{Cu}^{+}$and $\mathrm{Fe}^{2+}$ as tetrahedral cations, the virtual $\mathrm{N}_{\text {kobell }}$ is 2.2 for the Bruchatý grúnik nuffieldite, 2.11 for the low-Cu nuffieldite from Hviezda and 2.42 for the high-Cu Slovinky nuffieldite. These results may be compared with the virtual $\mathrm{N}$ values of 2.38 and 2.68, respectively, for the nuffieldite from Lime Creek (Harris 1993) and for the Cu-rich variety from Les Houches (Moëlo 1989). Thus, the results from our samples do not deviate in principle from those obtained from the type nuffieldite. To avoid confusion with kobellite $(\mathrm{N}=2)$, the ratio of tetrahedral cations to large cations can be used. Assuming two tetrahedral sites per formula unit, the nuffieldites from Bruchatý grúnik, Hviezda and Slovinky yield formulas of $\mathrm{T}_{2} \mathrm{M}_{7.02} \mathrm{~S}_{10.45} ; \mathrm{T}_{2} \mathrm{M}_{9.49} \mathrm{~S}_{13.3}$ and $\mathrm{T}_{2} \mathrm{M}_{7.62} \mathrm{~S}_{10.69}$ respectively; these are very different from the ratios in kobellite $\left(\mathrm{T}_{2} \mathrm{M}_{26} \mathrm{~S}_{35}\right)$.

The role of $\mathrm{Fe}$ in the nuffieldite structure was also investigated. In the compositional (Bi,Sb)-Pb-Cu diagram (Fig. 3), $\mathrm{Fe}^{2+}$ is lumped together with tetrahedral $\mathrm{Cu}^{+}$whereas in the second diagram (Fig. 3), it is present in a nearly octahedral site and added to $\mathrm{Pb}$. Amounts of Fe are negligible except in the case of the nuffieldite from the Bruchatý grúnik locality and in Cook's (1997) Baia Borsa material. The two diagrams (Fig. 3) show clearly that the bulk of the Fe follows the second scheme; the analyses in the $(\mathrm{Cu}+\mathrm{Ag})-(\mathrm{Pb}+\mathrm{Fe})-(\mathrm{Bi}+\mathrm{Sb})$ plot lie close to the compositional line between the unsubstituted- and substituted nuffieldite leaving only a minimum potential role for tetrahedral $\mathrm{Fe}^{2+}-$ reflected in the very small deviation from the line. The content of antimony is variable and depends on the degree of substitution.

\section{DISCUSSION}

The current investigations have confirmed the general formula for nuffieldite as $\mathrm{Cu}_{1+\mathrm{x}} \mathrm{Pb}_{2} \mathrm{Bi}_{2}\left(\mathrm{~Pb}_{\mathrm{x}} \mathrm{Sb}_{\mathrm{y}} \mathrm{Bi}_{1-\mathrm{x}-\mathrm{y}}\right) \mathrm{S}_{7}$ and an aikinite-type substitution as proposed by Moëlo (1989). Our results also corroborate the suggestion that antimony is necessary to stabilize nuffieldite in nature. The content of antimony (y) varies from 0.15 (Harris 1993) up to 0.48 (Cook 1997) but never exceeds 0.5. Maurel and Moëlo (1990) and Moëlo (1989) assumed that $\mathrm{Sb}$ enters the structure by simple $\mathrm{Sb}=\mathrm{Bi}$ substitution. However, this does not lead to a straightforward inverse correlation between Bi and Sb. Sb may occupy part of the mixed position as suggested by Moëlo et al. (1997) and can be involved in the coupled $\mathrm{Pb}+\mathrm{Cu}$ substitution in the same way as some of the Bi. 
The decreasing content of antimony with higher degrees of substitution could eventually lead to an antimony-free member. This was assumed by Ciobanu and Cook (2000), who reported Sb-free nuffieldite with an x value of 0.65 from Ocna de Fier, Romania. However, the position of the nuffieldite analyses from Ocna de Fier in Figure 2 shows a quite different substitutional trend. Thus, Ciobanu and Cook's (2000) data could represent a mixture of other minerals or a new phase. The analyses published by Moëlo (1989), Maurel and Moëlo (1990), Harris (1993) and Efimov et al. (1990) do suggest that the antimony content decreases with higher degrees of substitution. Other published analyses (Yudovskaya et al, 1992; Mozgova et al. 1994; Cook 1997) are too heterogeneous to allow comment on this. Nevertheless, a possible Sb-free member formed under appropriate specific conditions cannot be excluded.

No fully unsubstituted member is known at this time. As reported here, values for $x \approx 0.06$ characterise the nuffieldite from Hviezda. The next lowest substitution value $(x=0.09)$ was observed by Cook (1997) in Baia Borsa. Nuffieldites from the two other localities described in this paper have substitution values within the principal field of published analyses. However, only the values of Cook (1997) approach the high Fe content of the Bruchatý grúnik material; they behave in the same way in Figure 2. Only a few published analyses exceed $x$ values of 0.3 , e.g., some analyses in Yudovskaya et al. 1992, Moëlo 1989 and by others. The most substituted nuffieldite newly reported here has the mean formula $\mathrm{Cu}_{1.34} \mathrm{~Pb}_{2} \mathrm{Bi}_{2}\left(\mathrm{~Pb}_{0.23} \mathrm{Fe}_{0.02} \mathrm{Sb}_{0.32} \mathrm{Bi}_{0.43}\right)_{1} \mathrm{~S}_{7.03}$. Ciobanu and Cook (2000) reported the highest value of $x=0.65$ observed by in the Ocna de Fier locality; problems with this data were discussed above.

\section{CONCLUSIONS}

The general formula of nuffieldite $\mathrm{Cu}_{1+\mathrm{x}} \mathrm{Pb}_{2} \mathrm{Bi}_{2}\left(\mathrm{~Pb}_{\mathrm{x}} \mathrm{Sb}_{\mathrm{y}} \mathrm{Bi}_{1-\mathrm{x}-\mathrm{y}}\right) \mathrm{S}_{7}$ proposed by Moëlo (1989) has been confirmed in new occurrences of nuffieldite from Slovakia. The aikinite-type substitution $\mathrm{Pb}+\mathrm{Cu}=(\mathrm{Sb}, \mathrm{Bi})+\mathrm{Cu}$ with a preferential role of antimony, and which is in agreement with published data, is proposed. The least substituted nuffieldite analysed to date is reported. Values of $\mathrm{x}$ and $\mathrm{y}$ have been determined over the intervals $0.06<\mathrm{x}<0.34$ and $0.32<\mathrm{y}<0.45$, respectively. Fe is shown to enter the nuffieldite structure by the simple $\mathrm{Fe} \leftrightarrow \mathrm{Pb}$ substitution. The contents of other elements analysed are very low.

Acknowledgements. The authors would like to thank Dr. B. Antal, Dr. D. Ozdín and Dr. J. Majzlan who provided the polished sections in which nuffieldite was discovered. A fruitful discussion with Dr. Dan Topa is also appreciated. This work was supported by the grant project VEGA No. 1/1027/04 and V-374-05-00. The financial support from Danish Council Research (Grant 9901772) is gratefully acknowledged. Constructive reviews by two unknown reviewers have helped a great deal in revising the manuscript. The authors would like to thank prof. P. Kennan for the language corrections.

\section{REFERENCES}

ANTAL B., 1991a: Bi sulphosalts from Slovinky deposit. Mineralia Slovaca, 368 (in Slovak). 
ANTAL B., 1991b: Stannite from Slovinky deposit. Mineralia Slovaca, 185-186 (in Slovak).

CIOBANU C.L., COOK N.J., 2000: Intergrowths of bismuth sulphosalts from the Ocna de Fier Fe-skarn deposit, Banat, Southwest Romania. European Journal of Mineralogy 12, 899-917.

COOK N.J., 1997: Bismuth and bismuth antimony sulphosalts from Neogene vein mineralization, Baia Borsa area, Maramures, Romania. Mineralogical Magazine 61, 387-409.

EFIMOV A.V., BORODAEV YU. S., MOZGOVA N.N., NENASHEVA S.N., 1990: Peculiarities of bismuth mineralization at the Akchatau molybdenum-tungsten deposit (central Kazakhstan). Geol. Rudn. Mestorozd. 4, 64-75 (in Russian).

HARRIS D.C., 1993: Confirmation of antimony in co-type nuffieldite, Lime Creek, British Columbia and a second occurrence at Izok Lake, Northwest territories. Geological Survey of Canada Paper 93-1E, 9-10.

HURNÝ J., KRIŠTÍN J., 1978: Chemical composition of bismuth minerals from some deposits of the northern part of the Spissko-Gemerske Rudohorie Mountains (eastern Slovakia). In: Int. Mineral. Assoc., XIth General Meet., Novosibirsk), Abstr. Vol., 142.

KINGSTON P.W., 1968: Studies of mineral sulphosalts. XXI. Nuffieldite, a new species. Canadian Mineralogist 9, 439-452.

KOHATSU I., WUENSCH B.J., 1973: The crystal structure of nuffieldite $\mathrm{Pb}_{2} \mathrm{Cu}(\mathrm{Pb}, \mathrm{Bi}) \mathrm{Bi}_{2} \mathrm{~S}_{7}$. Zeitschrift für Kristallographie 138, 343-365.

MAJZLAN J., CHOVAN M., 1997: Hydrothermal mineralization in the Mlynná dolina valley, Nízke Tatry Mts. Mineralia Slovaca 29,149-158. (in Slovak).

MAJZLAN J., OZDÍN D., 1995: Cu-Pb-Bi sulfosalts from Nízke Tatry Mts. Mineralia Slovaca 27, 290-292 (in Slovak).

MAUREL C., MOËLO Y., 1990: Synthese de la nuffieldite dans le systeme Bi-Pb-Sb-Cu-S. Canadian Mineralogist 28, 745-749.

MOËLO Y., 1989: Antimoine dans la nuffieldite associée a de la friedrichite (commune des Hauches, Alpes de Haute-Savoie); redefinition cristallochimique de la nuffieldite. CR Acad Sci. Paris 309 II, $1659-1664$.

MOËLO Y., MEERSCHAUT A., MAKOVICKY E., 1997: Refinement of the crystal structure of nuffieldite, $\mathrm{Pb}_{2} \mathrm{Cu}_{1,4}\left(\mathrm{~Pb}_{0,4} \mathrm{Bi}_{0,4} \mathrm{Sb}_{0,2}\right) \mathrm{Bi}_{2} \mathrm{~S}_{7}$ : structural relationships and genesis of complex lead sulfosalt structures. Canadian Mineralogist 35, 1497-1508.

MOZGOVA N.N., NENASHEVA S.N., BORODAYEV YU. S., YUDOVSKAYA M.A., 1994: Nuffieldite from the Maleevskoe massive sulfide deposit, Russia. Canadian Mineralogist 32, 359-364.

OZDÍN D,. CHOVAN M., 1999: New mineralogical and paragenetic knowledge about siderite veins in the vicinity of Vyšná Boca, Nízke Tatry Mts. Slovak Geological Magazine 5, 4, 255-271.

YUDOVSKAYA M.A., BRYZGALOV I.A., EREMIN N.I., PETROVA I.V., POZDNJAKOVA N.V., 1992: New data about antimony-bismuth mineralization in ores of Maleevskoe deposit (Rudnyj Altai). Vestnik Moskovskogo Univ., Ser. Geol. 2, 53-65 (in Russian).

ZAKRZEWSKI M., MAKOVICKY E., 1986: Izoklakeite from Vena, Sweden, and the kobellite homologous series. Canadian Mineralogist 24, 7-18. 
Jaroslav PRŠEK, Emil MAKOVICKY, Martin CHOVAN, Alexander SMIRNOV

\title{
O SKŁADZIE CHEMICZNYM ROSTWORU STAŁEGO NUFFIELDYTU Z SIARCZKOWYCH MINERALIZACJI W ZACHODNICH KARPATACH, SŁOWACJA
}

\author{
Streszczenie
}

Badaniom chemicznym poddane zostały rzadkie siarkosole - nuffieldyty z trzech lokalizacji na Słowacji. Nuffieldyt w tych lokalizacjach współwystępuje z innymi siarkosolami bogatymi $\mathrm{w}$ Bi i tetraedrytem. $\mathrm{Cu}+\mathrm{Pb}=\mathrm{Bi}, \mathrm{Sb}+$ vac. substytucja w nuffieldycie oraz generalny skład chemiczny $\mathrm{Cu}_{1+\mathrm{x}} \mathrm{Pb}_{2} \mathrm{Bi}_{2}\left(\mathrm{~Pb}_{\mathrm{x}} \mathrm{Sb}_{\mathrm{y}} \mathrm{Bi}_{1-\mathrm{x}-\mathrm{y}}\right) \mathrm{S}_{7}$, gdzie $0<\mathrm{x}<0,34$; i $0,32<\mathrm{y}<0,45$ została potwierdzona. Zawartość Sb maleje wraz ze wzrostem zawartości $\mathrm{Cu}$, wskazując na dominującą przewagę w nuffieldycie substytucji Bi nad Sb. 